\title{
AN EVALUATION OF VARIOUS LEGUMES AT HIGH ALTITUDE
}

\author{
D. J. Musgrave \\ Tara Hills High Country Research Station, MAF, Omarama
}

\section{A bstract}

The performance of 'Grasslands Huia' white clover, 'Grasslands Turoa and Pawera' red clovers, 'Grasslands Maku' lotus, alsike clover, Wairau lucerne, and a mixture of Mt Barker and Tallarook subterranean clovers was evaluated over five seasons on sunny and shady faces at $1070 \mathrm{~m}$ altitude in the MacKenzie basin, North Otago. Mean productions in tonnes/ha on sunny and shady sites respectively were: Huia 2.3 and 0.7 , Turoa 3.0 and 1.2, Pawera 3.8 and 1.4, Maku 2.5 and 0, Alsike 2.6 and 1.4, Wairau 2.3 and 0.8 , and the subterranean clovers nil. Their performance on these sites is discussed in relation to their possible use in mixtures for oversowing into tussock grasslands.

\section{INTRODUCTION}

The Legume traditionally used for oversowing in the South Island tussock grasslands has been white clover, with red and/ or alsike clovers added, usually as minor components of the mixture. Although these legumes have been recommended by many authors (e.g., Ludecke and Molloy, 1966; Cullen, 1972), little information is available on their relative merits and performance.

The aim of the present study was to provide information on the herbage production of the recently released 'Grasslands' cultivars - Pawera (Trifolium prafense) and Maku (Lotus pedunculatus) $\rightarrow$ and to evaluate the performance of the available legumes in terms of their potential for use in oversowing mixtures .

\section{EXPERIMENTAL}

The two sites used in the study were $100 \mathrm{~m}$ apart, on opposite slopes within a catchment, at $1070 \mathrm{~m}$ altitude. The original vegetation on the sunny aspect was a hard tussock (Festuca novae-zelandiae) association on a dry sub-hygrous yellow-grey earth. On the shady aspect there was a mixed snow tussock (Chionochloa rigida) /hard tussock association on a dry hygrous upland yellow-grown earth. 
The soils had the following 'Quick Test' values:

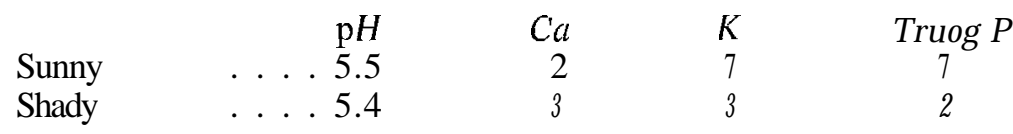

The sites were cultivated to a rubbly seedbed in the early spring, to ensure establishment and allow mowing. The sunny face was sown on September 17, 1971, the shady face on November $11,1971$.

The treatments, sown at seeding rates which gave approximately equivalent seed numbers to $3 \mathrm{~kg} / \mathrm{ha}$ of white clover, were:

'Grasslands Huia' white clover (T. repens)

Alsike clover (T. hybridum)

'Grasslands Turoa' red clover

'Grasslands Pawera' red clover

'Grasslands Maku' lotus

Wairau lucerne (Medicago sativa) - sown with $1250 \mathrm{~kg} /$ ha of lime

50/50 Mt Barker/Tallarook subterranean clover (T. subterraneum)

All were inoculated at 5 times the recommended rate with the appropriate commercial peat-based inoculant. A basal fertilizer dressing of molybdic superphosphate at $350 \mathrm{~kg} / \mathrm{ha}$ was applied at sowing and sulphur superphosphate (18\% elemental sulphur) was applied at $200 \mathrm{~kg} / \mathrm{ha}$ in 1973 and 1975 as maintenance dressings,

All animals were excluded throughout the 1971-76 period. The plots were not cut during the establishment year, but vigour scores and plant counts were taken.

TABLE 1: PLANT ESTABLISHMENT

(Plants/m' and vigour score on a O-5 scale)

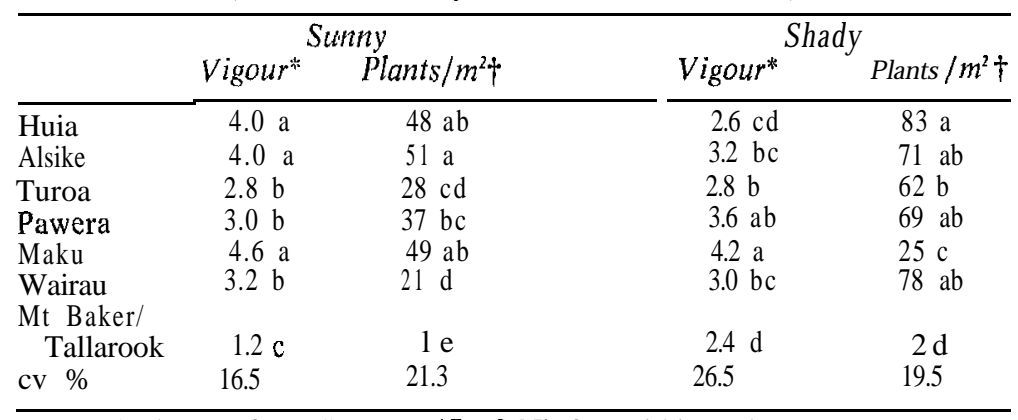

Duncan's letters for LSD test $(P<0.05)$ for within columns.

*April, 1972. †November, 1972. 
table 2: MEAN DRy matTeR PRODUCTION OVER FOUR SEASONS on THE SUNNY faCe (tonnes/ha - with equivalent log. values for totals)

\begin{tabular}{|c|c|c|c|c|c|c|c|c|c|c|c|c|c|c|}
\hline \multirow[b]{3}{*}{ Allsike } & \multirow{2}{*}{ Spring } & \multirow{2}{*}{\multicolumn{2}{|c|}{ Summer Total }} & & \multicolumn{3}{|c|}{$1973-4$} & \multicolumn{5}{|c|}{$1974-5$} & \multicolumn{2}{|c|}{$1975-6$} \\
\hline & & & & & Spring & Summer & Total & & Spring & ummer & Total & & Spring & $=$ Total \\
\hline & 1.88 & 1.41 & 3.96 & (1.24 ab) & 0.85 & 0.33 & a..98 & $(0.69 d))$ & 2.48 & a. 24 & 3.02 & $(1,32 \mathrm{~d} d)$ & 2. 688 & (1.213 abc) \\
\hline $\begin{array}{l}\text { Turno } \\
\text { Pawera } 2\end{array}$ & 2.210 & 0.67 & $2: 49$ & $(1.219 a b)$ & $1: 92$ & $8: 84$ & $2: 96$ & $(1.28$ ab) & 2.:78 & $2: 32$ & 5.99 & $\begin{array}{l}(1.79 a b) \\
(1.94 a)\end{array}$ & 2.65 & (1:28 ab) \\
\hline $\begin{array}{l}\text { Maku } \\
\text { Wairau }\end{array}$ & $\begin{array}{l}1.41 \\
1.16\end{array}$ & $\begin{array}{l}2.111 \\
0.30\end{array}$ & $\begin{array}{l}3.52 \\
1.46\end{array}$ & $\begin{array}{l}(1.50 \mathrm{a}) \\
(0.90 \mathrm{c})\end{array}$ & $\begin{array}{l}0.83 \\
0.95\end{array}$ & $\begin{array}{l}0.17 \\
0.53\end{array}$ & $\begin{array}{l}1.00 \\
1.48\end{array}$ & $\begin{array}{l}(0.68 \mathrm{~cd}) \\
(0.89 \mathrm{bc})\end{array}$ & $\begin{array}{l}2.58 \\
2.22\end{array}$ & $\begin{array}{l}1.90 \\
1.29\end{array}$ & $\begin{array}{l}4.48 \\
3.51\end{array}$ & $\begin{array}{l}(1.70 \mathrm{abc}) \\
(1.50 \mathrm{~cd})\end{array}$ & $\begin{array}{l}2.32 \\
2.94\end{array}$ & $\begin{array}{c}(1.19 b c) \\
(1.36 a b)\end{array}$ \\
\hline
\end{tabular}


In subsequent seasons cuts were taken to $3-5 \mathrm{~cm}$ as herbage production allowed - when the tallest plots were at the 15 $20 \mathrm{~cm}$ height. In most seasons this involved cuts at the end of the spring and summer on the sunny site and at the end of the summer on the shady site. Analysis of variance of annual production was performed on log, transformed values and an LSD test performed.

\section{RESULTS AND DISCUSSION}

Since the results (Tables 1-3) are restricted to two sites, they are discussed here in relation to the indications they give as to the possible use of these legumes for oversowing into other tussock grassland environments.

\section{White Clover}

Huia white clover established readily and on the sunny face was one of the most vigorous cultivars over the first two seasons (Tables 1 and 2).

Production in subsequent seasons on the sunny face and at all stages on the shady face (Table 3) was lower than from Pawera red clover and in many cases was lower than from the other cultivars.

Thus, although Huia has been the basis of the oversowing mixtures commonly recommended in the tussock grasslands (Ludecke and Molloy, 1966; Cullen, 1972), these results and those of Scott et al. (1974) suggest that other legumes could replace Huia in some oversowing situations.

TABLE 3: MEAN DRY MATTER PRODUCTION OVER FOUR SEASONS ON THE SHADY FACE

(tonnes/ha - with equivalent log, values; all production over the summer period)

\begin{tabular}{|c|c|c|c|c|c|c|c|}
\hline \multirow{3}{*}{$\begin{array}{l}\text { Huia } \\
\text { Alsike }\end{array}$} & \multicolumn{2}{|c|}{$1972-3$} & \multicolumn{2}{|c|}{ 1973-4 } & \multicolumn{2}{|c|}{$1974-5$} & $1975-6$ \\
\hline & 0.88 & $(0.63 \mathrm{~b})$ & 0.58 & $(0.45 c)$ & 0.87 & $(0.62$ b) & $0.64 \quad(0.48 \mathrm{~b})$ \\
\hline & 1.28 & $(0.81$ a) & 1.23 & $(0.79$ a) & 1.61 & $(0.94 \mathrm{a})$ & $1.33(0.84$ a) \\
\hline Turoa & 1.22 & $(0.79 \mathrm{ab})$ & 0.70 & $(0.53 \mathrm{bc})$ & 1.57 & $(0.94$ a) & $1.39 \quad\left(\begin{array}{ll}0.86 & a\end{array}\right)$ \\
\hline Pawera 1 & .13 & $(0.74 \mathrm{ab})$ & 1.01 & $(0.69 \mathrm{ab})$ & 1.83 & $0^{\cdots}$ a) & $1.52 \quad\left(\begin{array}{lll}0.91 & \mathrm{a}\end{array}\right)$ \\
\hline Maku & & 0 & & 0 & & $(0.73$ & 0 \\
\hline Wairau & 0.85 & $(0.62$ b $)$ & 0.95 & $(0.65 \mathrm{ab})$ & 1.14 & b) & $1.39 \quad(0.85 \quad \mathrm{a})$ \\
\hline
\end{tabular}

S.E.D. 0.088 


\section{ALSIKE}

Alsike showed good vigour over the first season and in subsequent seasons was among the highest producers, particularly on the shady site. The production was relatively evenly apportioned between spring and summer.

Scott et al. (1974) and Clifford (1975) have also reported favourably on the performance of alsike in this area, which suggests that alsike could usefully he considered as an alternative to Huia, at least in the MacKenzie basin.

\section{RED C LOVERS}

Pawera red clover was not exceptionally vigorous in the establishment year or over the second spring. From then on it produced as well as or better than the other cultivars over both spring and summer periods.

Scott et al. (1974) also found Pawera to be extremely productive, although in the drier situation under which their experiment was conducted lucerne gave higher production after 3 to 5 years. In a mixed sward on the flats at Invermay, Pawera has persisted much better than Turoa and maintained production over five years (I. R. McDonald, 1972, pers. comm.).

Turoa red clover behaved in a very similar manner to Pawera - although Pawera produced on average 26\% and $16 \%$ more dry matter on the sunny and shady faces, respectively. Scott et al. (1974) reported a similar difference between the cultivars.

\section{LOTUS}

As was reported by Armstrong (1974), Maku lotus has vigorous seedling growth and at the end of the first season Maku had the highest vigour score on both sites. Subsequently, on the shady site, where cultivation had removed the tussock cover, many of the plants were uprooted by frost heave or winter killed. The few plants which did survive were unthrifty and did not at any stage produce enough herbage to harvest.

On the sunny face, production from Maku was only average, except when favourable summer conditions were experienced, such as in 1972-3 and 1974-5, when production from Maku was similar to that from the two red clovers.

These results, and the poor production from Maku reported by Scott et al. (1974) at the drier site, suggest that Maku is favoured by damper summer conditions than were experienced on this site. 


\section{LUCEKIVE}

Wairau Lucerne established reasonably well at this altitude, although numbers were low on the sunny face. The vigour over the first season and production in the second spring were similar to those of the red clovers, but were lower over the second summer. In subsequent seasons, Wairau was at least as productive as Huia and over the dry $1975-6$ season produced substantially more.

At lower altitudes in the drier tussock grasslands Wairau has a definite place (Scott et al., 1974), particularly on the dry sunny faces (Musgrave, 1976). However, in slightly moister situations, the higher production obtained from Pawera suggests that it would be a better alternative.

\section{Subterranean Clover}

The subterranean clovers did not establish satisfactorily (Table 1). This does not appear to be a result of the time the experiment was sown, as previous work in this area has shown that spring sowing of subterranean clover is as successful as autumn sowing (1. R. McDonald, 1970, pers. comm.) : Small amounts of seed were set by the surviving plants and a few plants persisted throughout the duration of the trial, but their 'growth was very poor and no further data on their performance were collected.

Several. workers have evaluated subterranean cultivars at lower altitudes in similar areas with good results (Smetham, 1968; Scott, 1971; I. R. McDonald, 1972, pers. comm.) so it seems likely that $1000 \mathrm{~m}$ in this area is approaching the altitudinal limit for the growth of subterranean clover.

\section{CONCLUSIONS}

Although Huia white clover is an adaptable legume, the performance of the other cultivars reported here shows that there are situations where they may be more suitable than Huia. The main advantage that Huia has is its ability to spread into uncolonized areas and there are many situations in tussock grasslands where the soil stabilizing influence of Huia warrants -its- inclusion in an oversowirig mixture,

Since there are several factors affecting the performance of an oversown mixture (such as the ability to withstand grazing pressure), which were not considered in this experiment, these results can only be taken as a guide to the potential of the cultivars sown. The good performance of the red clovers, particularly 
Pawera, suggests that they could well be considered as a major component of a mixture, particularly for drier situations. Similarly, alsike should be considered as a major component for colder situations, particularly in the MacKenzie basin.

Although Maku has demonstrated its potential for growth, particularly in wetter summers, there are doubts about its ability to withstand competition in a mixed legume sowing (Lowther, 1976) which may limit its use to specialized situations. Similarly, Wairau has a specialized place in drier situations where less drought-tolerant legumes do not persist satisfactorily.

\section{ACKNOWLEDGEMENTS}

To I. R. McDonald for assistance and unpublished data, T. R. Wallis, R. I. Paton and J. R. Robertson for technical assistance, and Dr G. H. Jowett for assistance with statistical analysis,

\section{REFERENCES}

Armstrong, C. S. M., 1974. N.Z. Jl exp. Agric., 2: 333-6.

Clifford, P. T. P., 1975. Ibid., 3: 235-8.

Cullen, N. A., 1972. Proc. N.Z. Grassld Ass., 34: 63-70.

Lowther, W. L.. 1976. Proc. N.Z. Grassld Ass.. 38: 133-9.

Ludecke, T. E.; Mollov B. J. P., 1966. Proc. N.Z. Grassld Ass., 28: 46-58.

Musgrave, D. J., 1976. Rev. Tussock Grassdl Mount. Lands Inst., 33: in press.

Scott, W. R , 1971. Ausf. J. exp. Agric. Anim. Husb., 11: 202-6.

Scott, D.; Stringer, G. C.; O'Connor, K. F.; Clifford, P. T. P., 1974. N.Z. $/$ l exp. Agric., 2: 251-9.

Smetham, M. L., 1968. Proc. N.Z. Grassld Ass., 30: 114-21. 